UDK 330.1.474

Hryniuk I., Postgraduate student, Ivano-Frankivsk National Technical University of Oil and Gas

\title{
DEPRECIATION AS A SOURCE OF CURRENT CAPITAL FINANCING
}

Funding of assets is a central issue in the work of managers. In accordance with the "golden" balance sheet rule, sources of financing are considered from owners' equity and liabilities, which on terms of use correspond to assets. However, in practice, compliance with this approach is rather laborious, and sometimes it's irrational, as some long-term sources finance short-term (current) assets, and short-term sources finance long-term (non-current) assets. It is important to note that the process of the formation and actual using of certain sources of financing, in particular, accumulated profit and depreciation, not always comply with this rule. In present time, most researchers consider depreciation only as a source of renewal of fixed assets, leaving out the fact that these funds will remain in current capital and finance the current activities of the company, until the moment of direct renewal of noncurrent assets. It consider to expedient to consider in more detail the equity capital and its components as sources of current capital financing.

Key words: current capital, own capital, depreciation, income.

Fig. 6, Bibl. 7

\section{Гринюк І. М.}

\section{АМОРТИЗАЦІЯ ЯК ДЖЕРЕЛО ФІНАНСУВАННЯ ОБОРОТНОГО КАПІТАЛУ}

Фінансування активів є центральним питанням у роботі менеджерів. Відповідно до «золотого» правила балансу, джерела фінансування включають власний капітал та зобов'язань (поточних та довготермінових), які за термінами використання відповідають активам. Проте, на практиці, дотримання такого підходу є досить трудомістким, а іноді ірраціональним, оскільки деякі довготермінові джерела фінансують короткотермінові (поточні) активи, а короткотермінові джерела фінансують довготермінові активи. Важливо відзначити, що процес формування та фактичного використання певних джерел фінансування, зокрема, накопичений прибуток і амортизація, не завжди відповідають даному правилу. В даний час більшість науковців розглядають амортизацію лише як джерело відновлення основних засобів, не враховуючи того, що ці кошти залишаться у поточному капіталі та фінансують поточну діяльність компанії, до моменту прямого поновлення довготермінових активів. Доцільно більш детально розглянути власний капітал та його компоненти як джерела фінансування поточного капіталу.

Ключові слова: оборотний капітал, власний капітал, амортизація, прибуток.

Гринюк И.Н.

\section{АМОРТИЗАЦИЯ КАК ИСТОЧНИК ФИНАНСИРОВАНИЯ ОБОРОТНОГО КАПИТАЛА}

Финансирования активов является центральным вопросом в работе менеджеров. В соответствии с «золотым» правилом баланса, источники финансирования включают собственный капитал и обязательств (текущих и долгосрочных), которые по срокам использования соответствуют активам. Однако, на практике, соблюдение такого подхода является достаточно трудоемким, а иногда иррациональным, поскольку 
некоторые долгосрочные источники финансируют краткосрочные (текущие) активы, а краткосрочные источники финансируют долгосрочные активы. Важно отметить, что процесс формирования и фактического использования определенных источников финансирования, в частности, накопленная прибыль и амортизация, не всегда соответствуют данному правилу. В настоящее время большинство ученых рассматривают амортизацию только как источник обновления основных средств, не считая того, что эти средства останутся в текущем капитале и финансируют текущую деятельность компании, до момента прямого обновления долгосрочных активов. Целесообразно более подробно рассмотреть собственный капитал и его компоненты как источника финансирования текущего капитала.

Ключевые слова: оборотный капитал, собственный капитал, амортизация, прибыль.

1 Introduction. Current capital is an important part of the enterprise's assets, it require an individual approach and a special concern for the management of the enterprise. Its consists from stokes, accounts receivable and cash. This is due, firstly, to the fact that this capital includes assets vital in terms of doing business - those whose value are set by the company (for example, materials, finished products, goods) or those that are related with its results (for example, cash, accounts receivable). The second reason for the importance of current capital for an enterprise is the fact that the higher its level, that more money is frozen in its components, which negatively affects the company's liquidity.

Questions related to the process of formation and appointment of financing sources of the enterprise's assets has been a long way of formation and development and considered in the papers of many researches. The most significant contribution to the development of the theories of current capital financing and depreciation and income role in it was made by such prominent researches as Golov S., Kafka S., Lenskaia S., Lovinska L., Orlova V., Pyrih I., Khoma (Sanchishak) S., Khomyn P., Chumachenko M. and other.

The aim of the article is to substantiate the depreciation fund as the source of current capital financing, as opposed to the widespread view of financing due to the depreciation of highly non-current assets.

2 Conceptual framework and literature review. The most controversial part of own capital is depreciation. It forms to based on the non-current assets but in the process of economic activity it'll be conceder with other assets. In accordance with IAS 16 "Property, Plant and Equipment": "depreciation is the systematic allocation of the depreciable amount of an asset over its useful life" (IAS 16). Some economists treat depreciation recovered from sales as a "source of financing for simple reproduction of non-current assets" (Holov, 2004; Chumachenko, 2004; Lovinska, 2006; Khomyn, Pyrig, 2007). Non-current assets don't require permanent financing in the course of economic activity. Whereas depreciation based on their value in the process of activity change its size and form cash of the enterprise on its account. The treatment of depreciation not connected with non-current assets isn't inherent to economic literature.

The "golden" balance sheet rule says that the terms of liability payments must correspond to the using terms of assets. According to this rule, long-term assets of the enterprise should be financed by means of long-term sources. Thus, the term of payment of a long-term loan borrowed to finance non-current assets should not exceed the period of depreciation of this asset. Instead, current assets should be financed only by short-term liabilities. Regarding this rule, a large number of allegations can be formulated, in opposition to, for example, that this wording does not consider the possibility of forming a new type of capital, nor the financing of obligations that exceeded its original planned term. Accordance 
with this rule, the company also does not receive guarantees of maintenance of financial liquidity, and also, loss of solvency. However, this rule should be a starting point for the company, which should be taken into account when deciding on how to fund assets when planning a "reasonable" risk, that is, that does not pose a threat to the enterprise. This rule ensures that the assets of the enterprise, which are divided into current and non-current, correspond to the long-term and short-term capital in the liability. However, this rule has a narrower interpretation. In the literature can be observe a partial deviation from this rule. The implementation of the rule in this form limits the possibility of increasing the return on equity through the use of cheaper external sources of funding.

L. Bednarski (Bednarski, 2001) and his colleagues often criticize this rule in their writings. In their opinion, it has a general character and a detailed dimension in much generalized figures, because the data obtained from the balance sheet of an enterprise show the state of assets, capital and liabilities of the company on the day of its compilation. In fact, the balance sheet does not cover the overall financial situation of the enterprise, including information on the company's previous needs for assets and the ability to attract new capital. It's not possible to reject this rule, however, when it using it's appropriate to analyze and other information also. The "golden" balance sheet rule describes the general provisions for the classification of assets and liabilities over useful time of live, but this approach is not suitable for allocating funding sources for a specific period of activity. It is necessary to consider in more detail the composition of liabilities of the enterprise with the allocation of those components that finance current capital, that is, the current activities of the enterprise, especially equity components that, in accordance with this rule, finance only non-current assets.

In the economic literature this rule is used to assign sources of asset financing throughout the life cycle of an enterprise. Such allocation of sources of funding is appropriate only for newly created enterprises. In the process of economic activity enterprises form their own results and other types of property, therefore, the designated sources of funding is impossible only by the same methodology. For this reason it's expedient to consider in more detail the components of the company's equity capital and to distinguish those who in the process of economic activity will be financed those assets which will be an active component of its activities and will still look for sources of funding.

It is important to study the process of forming and using depreciation in the process of economic activity of the enterprise until the moment of its write-off from the balance sheet and to prove that the depreciation fund should be investigated not only in relation to noncurrent assets but also in the finding's process of financing sources for the current activity of the enterprise, that is, the active part of the assets of the enterprise.

3 Research justifications. The main result of the enterprise's activity is its profit. Despite the fact that, from the accounting point of view, undivided profit is a long-term financing source and, in accordance with the "golden" balance sheet rule, should be the source of long-term assets' financing, but the profit is the main source of current capital financing. The resulting profit from the enterprise will be the source of current capital financing, if the economic activity doesn't require investments in non-current assets.

In the process of production the enterprise carries a number of costs that are grouped on the basis of similarity in the groups (items) of costing: raw materials; technological energy; maintenance and operation costs of the equipment; salary of production workers; overhead costs; other production costs; non-productive costs. Costs of these items constitute the full (commercial) cost of production, that is, all costs incurred by the enterprise for the production of products. Formation of the price of finished goods is carried out by adding the commercial 
cost of products, the planned amount of profit from the sale of these products and indirect taxes paid by the enterprise in accordance with the taxation system.

If to ignore the investment and financial activity, the percentage of profitability put in the price will form the amount of undivided profit for the reporting period. This amount will finance current capital in the future. The value of assets that were financed and spent in the past will be returned by including in the sales price the cost of production. These costs are repaid by the company by cash, reducing the amount of current capital, or increasing its current liabilities, which will be settled by cash in the future. The funds received from the sale of products will return the money spent on the production of this product.

Circulation of cash in the enterprise is continuous. A part of cash is removed from circulation through the acquisition of other assets. When acquiring working assets (stocks), these funds will be returned together with proceeds from sales in a period not exceeding one year. The magnitude of their return will be arbitrary in connection with the uneven timing and extent of implementation. However, the cash spent on the purchase of non-current assets will be returned to the enterprise in parts for several years, as the amount of accrued depreciation, which is included in the cost of sales.

The most controversial article in the calculation is the cost of maintenance and operation costs of the equipment, in particular its component, such as depreciation of noncurrent assets.

We do not agree with opinion that the depreciation financed only non-current assets, because being an integral part of the income, depreciation comes in cash terms to the enterprise with the proceeds from the sale and is kept on the bank's account (Fig. 1).

\begin{tabular}{|l|r|r|l|l|r|r|}
\hline & \multicolumn{1}{|c|}{$\mathbf{2 0} \mathbf{2 0}^{\prime}$} & \multicolumn{1}{|c|}{ (20” } & $\mathbf{2 0}$ \\
\hline Assets & & & Owner's Equity & & \\
\hline $\begin{array}{l}\text { Property, plant and } \\
\text { equipment: }\end{array}$ & 1000 & 1000 & Undivided profit & 1000 & 1000 \\
\hline machinery and equipment & $(200)$ & $(230)$ & Total owners' equity & $\mathbf{1 2 0 0}$ & $\mathbf{1 3 5 0}$ \\
\hline accumulated depreciation & $\mathbf{8 0 0}$ & $\mathbf{7 7 0}$ & $\begin{array}{l}\text { Total liabilities and } \\
\text { owners' equity }\end{array}$ & $\mathbf{1 2 0 0}$ & $\mathbf{1 3 5 0}$ \\
\hline Property and equipment, net & & & & & \\
\hline Current assets: & 20 & 30 & & & \\
\hline Stocks & 380 & 540 & & & \\
\hline Cash & $\mathbf{4 0 0}$ & $\mathbf{5 8 0}$ & & & \\
\hline Total current assets & $\mathbf{1 2 0 0}$ & $\mathbf{1 3 5 0}$ & & & \\
\hline Total assets & & & & & \\
\hline
\end{tabular}

Figure 1 - Display in the balance sheet the changes due to product sales Source: developed by the author

Thus, depreciation is a source of current capital financing. Subsequently, these funds can be spent on the purchase of as current and as non-current assets, or to be invested in order to generate additional profits in the future. Depreciation reduces the carrying value of fixed assets, its redemption remains in cash on the bank's account of the enterprise (Fig. 2). 


\begin{tabular}{|c|c|c|c|}
\hline Assets & & Owner's Equity & \\
\hline Property, plant and equipment: & & Undivided profit & 1100 \\
\hline - Machinery and equipment & 1000 & & \\
\hline - accumulated depreciation & $(200) \leftarrow$ & Depreciation & 200 \\
\hline Property and equipment, net & 800 & & \\
\hline \multicolumn{4}{|l|}{ Current assets: } \\
\hline Cash & 5000 & & \\
\hline Including depreciation & 200 & & \\
\hline
\end{tabular}

Figure 2 - Depreciation in balance sheet items

Source: developed by the author

So, as a depreciation is one of the components of producing cost, it means the costs incurred by the enterprise in the process of manufacturing of products, it can not be a source of renewal in the future, because it is a return of previously incurred costs for the formation of non-current capital. Acquisition of non-current assets is carried out by spending cash, i.e. current assets (cash) are transferred to non-current assets (fixed assets). Depreciation deductions return these funds from the composition of irreversible to the composition of current assets.

Depreciation may be a source of financing only if the enterprise received a profit in the reporting period. In the event that the enterprise received a loss on the basis of the reporting period, the amount of depreciation, which was entered in the cost price, can not serve as a source of financing of any type of assets, since the loss reduces the amount of equity capital. The amount of accrued depreciation remains in the company as an account receivables and enters to the enterprise in the form of cash, together with the proceeds from the sale. For loss-making activity, all cash received from sales of products should be used to pay off the account payables that arose in the process of manufacturing these products. In this case, depreciation can not serve as a source of asset financing, since a depreciation fund will not be created and will it require funding. And in the absence of profit, financing will be provided at the expense of external sources. If the amount of depreciation accrued in the reporting period more than a loss, their difference will remain in the current assets.

Depreciation has another one feature. All expenses for production (materials, labour, energy resources, etc.) were incurred in the current period and were focused on the production of a specific batch of finished products. Instead, the acquisition of fixed assets is carried out once for several subsequent periods (years) and over the course of time their value is transferred to costs (depreciated). The proceeds from the sale can be divided into two parts: cash, which will be used to cover current costs (raw materials, salary, other costs) and cash, which will remain in the enterprise and will finance the further activity of the enterprise (depreciation and profit) (Figure 3).

For the loss-making activity, the funds to be repaid most often equal or exceed the proceeds from sales, which is why the company does not have the funds to finance the needs of the enterprise. The funds returned as depreciation will be used to pay off the account payables and will not remain in the enterprise to finance the assets. Technically, in order to pay off all costs incurred by an enterprise, it is necessary to raise funds in the amount of the loss reduced by the amount of depreciation. If the amount of depreciation accrued in the reporting period exceeds the loss, their difference will remain in current assets and will be a source of financing. 
Proceeds from sales

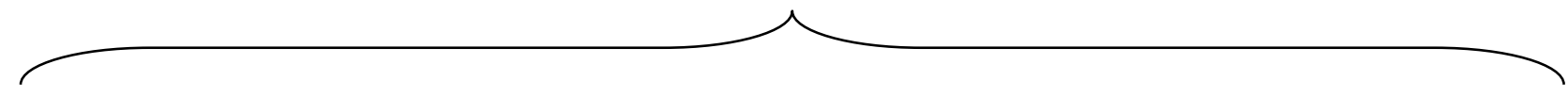

Cost of production

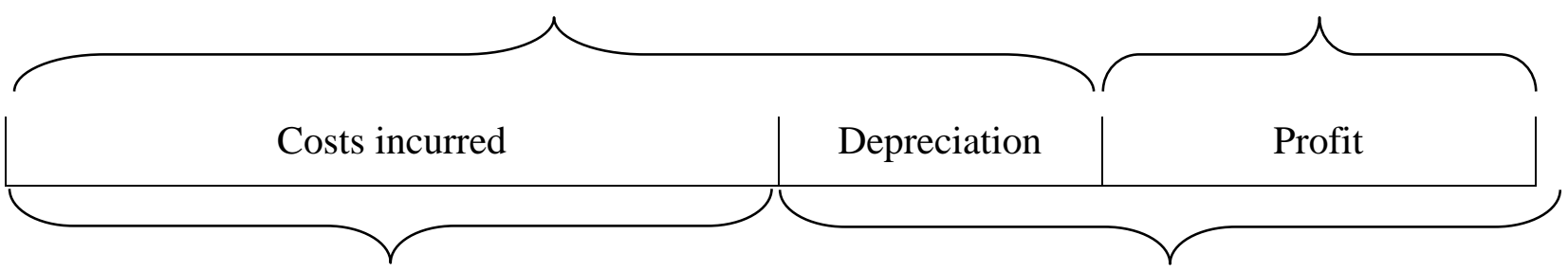

Funds that have a direct purpose

The funds remaining at the enterprise

Figure 3 - Ingredients of prices

Source: developed by the author

Speaking about the financing of assets in the process of economic activity, it should be noted that included in a certain group of liabilities or the capital of the enterprise can serve as a source of financing both non-current and current assets. For example, purchased in the reporting period on post-payment terms (at own cash) fixed assets will be shown as noncurrent assets, while the actual source of their financing (account payables) will be reflected in the short-term liabilities of the enterprise. Also, as shown in Fig. 3, if the company is profitable, the profits will be financed by working capital, since cash which is attributable to depreciation and profit, will remain in the cash out of the bank's accounts.

Relying on the general form of movement of means of production, according to which the process of their restoration is carried out continuously in the form of their cycle, passing certain stages and changing their form on each of them. The founder of the theory of capital turnover was Karl Marx. According to his theory, the initial form of circulation of working capital is monetary. The following form of which acquires circulating assets in the production process is commodity. In the process of production, with the participation of means of production and labour, the product gets more value. As a result, at the last stage of the turnover, the goods are converted into cash. Marx showed this dependence as follows (Fig. 4).

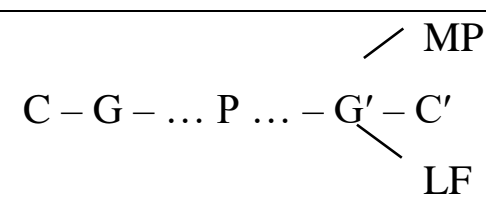

Figure 4 - K. Marx's capitalist mode of production

$C$ - money; $G$-good; $\quad \mathrm{P}$ - production; $G^{\prime}$ - increased value added goods;

$C^{\prime}$ - increased value added cash $\quad L F$ - labour; force; $M P$ - means of production; Source:[6]

Analyzing the process of current capital financing, the process of its circulation, on a similar principle, can be represented as follows (Figure 5). 


$$
C M G\left(\begin{array}{l}
R M \\
T E \\
E \\
S \\
O C \\
O P C \\
N P C
\end{array}\right)+I=R=A R \rightarrow C\left(\begin{array}{l}
R M \\
T E \\
E \\
S \\
O C \\
O P C \\
N P C \\
I
\end{array}\right) \rightarrow C M G^{\prime}\left(\begin{array}{l}
R M^{\prime} \\
T E^{\prime} \\
E^{\prime} \\
S^{\prime} \\
O C^{\prime} \\
O P C^{\prime} \\
N P C^{\prime}
\end{array}\right)+I^{\prime}
$$

$C M G$-cost of manufactured goods;

$R M$ - raw materials;

$T E$ - technological energy;

$E$ - maintenance and operation costs of the equipment;

$S$ - salary of production workers;

$O C$ - overhead costs;

$O P C$ - other production costs;

Figure 5 - The model of circulation of current capital in the process of economic activity
$N P C$ - non-productive costs;

$I$ - income included in the price;

$R$ - revenue;

$A R$ - account receivables;

$C$ - cash;

...' -indicates the corresponding item in the next production cycle.

Source: developed by the author

In the process of business activity, all incurred costs $(C M G)$ will be repaid by cash $(C)$, received from repayment of account receivables $(A R)$ for the realized products of the enterprise $(R)$. These funds will be offset by arrears below the cost of the next batch of products: obligations for purchased raw materials, payments for energy resources, payment of wages and taxes related to it, as well as other expenses related to production $(O C, O P C$, $N P C)$. Instead, the amount of depreciation deductions $(E)$ included in cost $(C M G)$, returning to cash $\left(C^{\prime}\right)$ will not have a specific purpose when converted and will remain in the bank's account. Similarly, the profit $(I)$ will remain on the current account in the bank.

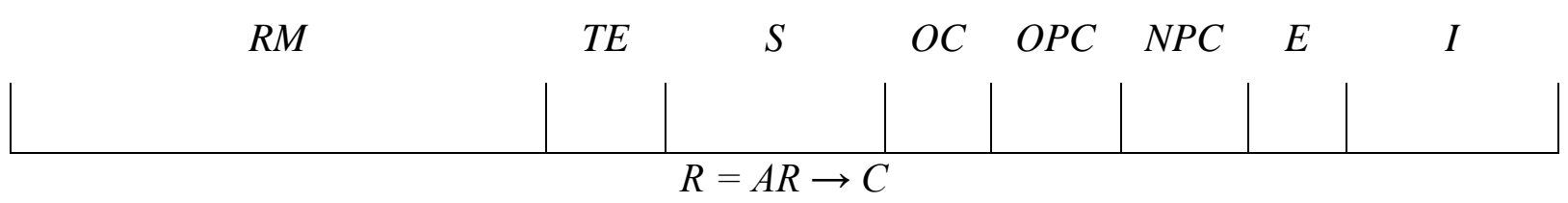

Figure 6 - Structure of proceeds from the sale of finished products

Source: developed by the author

Thus (fig. 6), current capital will be financed not only at the expense of short-term sources, but also due to part of equity, that is, accumulated net profit and accumulated depreciation. As for depreciation, it should be considered its accounting reflection. Accounting for accrued depreciation is carried out on a passive account "Depreciation of noncurrent assets", however, when forming financial statements, in "Balance sheet" (Financial Statement), this account is reflected in the first section of the asset - non-current assets. Based on the economic treatment of non-current assets as such, the useful life of which is more than 1 year, depreciation deductions will be formed at the enterprise for more than one year. That is why it is expedient to attribute accumulated depreciation to long-term sources of financing, namely to equity, since it is formed at the expense of existing own sources of the enterprise. 
As depreciation and retained earnings are part of equity, but they finance current capital in the form of cash received from sales proceeds or account receivables that will be settled by cash in the future, we propose the use of an economic category such as long-term current founds.

Long-term current founds (LTCF) are a part of the company's equity (retained earnings and accumulated depreciation), which forms part of current capital and are used to finance it.

In addition, current liabilities will also be the source of current capital financing. That is why it is expedient to consider as the source of current capital financing the sum of three items: short-term liabilities, retained earnings and accumulated depreciation, which are longterm current founds.

Main results: 1 . Depreciation can not be considered as a source of financing of noncurrent assets, because according to its economic essence, it is the returning of the value of already existing non-current assets. Non-current assets do not require funding in the course of their useful use.

2. The depreciation fund is formed on the basis of non-current assets is a component of the enterprise's own capital. This fund, by including it in the cost of sales, is returned in cash and it's a significant source of financing of current capital of the enterprise.

3. The funds received as sales proceeds are divided into two categories: those that have a direct purpose and return the incurred earlier payments, and those that remaining in the enterprise and will be used in the future by the enterprise. This division makes it possible to distinguish two main components that will finance the current activities of the company: depreciation and profit.

4. The process of forming the cost of sales of products and income of the enterprise (proceeds from sales) has a cyclic nature. Thus, it can be represented as a model of circulation, which characterizing the process of forming the components of owner's equity, which will be funded current capital of enterprise.

5. Current capital is funded by several owner's equity articles (items), it is proposed to introduce the economic category "Long-term current founds", which will characterize longterm sources of current capital financing.

\section{Reference:}

1. International Accounting Standard 16 Property, Plant and Equipment. http://www.frascanada.ca/international-financial-reporting-

standards/resources/unaccompanied-ifrss/item45609.pdf

2. Holov, S. Concepts of depreciation and it influence on accounting and management in modern conditions (Концепції амортизації та їх вплив на облік i управління в сучасних умовах). Бухгалтерський облік і аудит, 2004. - 8: p. 9-15

3. Chumachenko, M. Amortization deductions are an essential source of financing of enterprise investments (Амортизаційні відрахування - суттєве джерело фінансування інвестицій підприємства). Бухгалтерський облік і аудит, 2004 - 8: p. 6-9

4. Lovinska, L. Accrual of depreciation is a way to regulate the balance sheet valuation of long-term assets (Нарахування зносу - спосіб регулювання балансової оцінки довгострокових активів). Фінанси України, 2006. - 7: p. 92-100

5. Khomyn, P., Pyrig, I. Depreciation: economic content and method of reflection (амортизація: економічний зміст та методика відображення). Фінанси України, 2007, 6: p. 22-30

6. Marx, K.. Capital: Critique of Political Economy v. 2 (Penguin Classics) 2. Moskow: Политиздат, 1984, p. 116

7. Bednarski, L. 2001. Analiza ekonomiczna przedsiębiorstwa. Wrocław, Wydawnictwo AE im. Oskara Langego: 103 